\title{
The effect of live yeast, Saccharomyces cerevisiae, and their metabolites on ciliate fauna, fibrolytic and amylolytic activity, carbohydrate digestion and fermentation in the rumen of goats
}

\author{
B. Kowalik ${ }^{1}$, T. Michałowski, J.J. Pająk, M. Taciak and M. Zalewska
}

\author{
The Kielanowski Institute of Animal Physiology and Nutrition, \\ Polish Academy of Sciences \\ 05-110 Jablonna, Poland
}

(Received 31 August 2011; revised version 30 November 2011; accepted 6 December 2011)

\begin{abstract}
The influence of live Saccharomyces cerevisiae cells and their metabolites on the number of ciliates and some fibrolytic and amylolytic enzymes, together with the effect on the concentration of volatile fatty acids (VFA), and disappearance of dry matter (DM) and structural carbohydrates in the rumen of three goats was examined. The control diet $\left(1.2 \mathrm{~kg} \mathrm{DM} \cdot \mathrm{d}^{-1}\right)$ was composed of hay $(63 \%)$, barley meal $(31 \%)$, and soyabean meal (4\%). Two experimental rations consisting of the same components supplemented with either live Saccharomyces cerevisiae (CNCM I-1077) cells or their metabolites (Diamond V XP). The additives were supplied at the rate of 3 and $25 \mathrm{~g} \cdot \mathrm{d}^{-1}$, respectively. The experiment was carried out in a $3 \times 3$ Latin square design. Enrichment of the control diet with yeast metabolites increased $(\mathrm{P}<0.05)$ the total number of protozoa and the number of Diplodinium from 115 to $146 \times 10^{4}$ and from 2.5 to $6 \times 10^{4} \cdot \mathrm{g}^{-1}$ digesta, respectively. Conversely, the number of representatives of the genus Isotricha decreased over eightfold regardless of the additive used. The activity of carboxymethylocellulase was about $9.4 \mu \mathrm{M}$ released reducing sugars $\cdot \mathrm{g}^{-1} \mathrm{DM} \cdot \mathrm{min}^{-1}$ irrespective of diet, whereas xylan digestion increased from 57.5 to 69.7 and $70.4 \mu \mathrm{M}$ released reducing sugars $\cdot \mathrm{g}^{-1} \mathrm{DM} \cdot \mathrm{min}^{-1}$ when live yeast $(\mathrm{P}<0.05)$ or their metabolites $(\mathrm{P}<0.01)$ were added, respectively. On the other hand, amylolytic activity decreased from 58 to $50 \mu \mathrm{M}$ released reducing $(\mathrm{P}<0.05)$ sugars $\cdot \mathrm{g}^{-1} \mathrm{DM} \cdot \mathrm{min}^{-1}$ when the control diet was supplemented with viable Saccharomyces cerevisiae. Live yeast cells increased the disappearance of neutral detergent fibre (NDF) from 38 to $44.7 \%$ after in sacco incubation of hay in the rumen for $16 \mathrm{~h}(\mathrm{P}<0.05)$. The disappearance of neither $\mathrm{DM}$ nor acid detergent fibre was affected by the diet. Yeast metabolites decreased $(\mathrm{P}<0.01)$ total volatile fatty acids (VFA), whereas live yeast had no effect. Enrichment of the control diet with
\end{abstract}

${ }^{1}$ Corresponding author: e-mail: b.kowalik@ifzz.pan.pl 
live yeast increased $(\mathrm{P}<0.05)$ the molar proportion of acetate from 62 to $64 \%$ of total VFA. Both additives elevated the molar proportion of butyrate from 10.5 to 11.9 and $11.3 \%$ of total VFA, respectively $(\mathrm{P}<0.05)$ and lowered that of propionate. The acetate/propionate ratio in the rumen of goats fed the control diet and the diet supplemented with either live yeast $(\mathrm{P}<0.01)$ or their metabolites $(\mathrm{P}<0.05)$ was $2.7,3.1$ and 2.9 , respectively. The yeast metabolites increased ruminal $\mathrm{pH}$ from 6.5 to 6.7 . No changes in acidity were found when live yeast were added.

KEY WORDS: yeast, rumen, protozoa, carboxymethyl cellulase, xylan, amylase, VFA, NDF, goat

\section{INTRODUCTION}

Two types of yeast additives are currently in use, i.e. live yeast cells and yeast metabolites. Their beneficial influence has been reported in relation to animal health as well as daily gain and milk production (Mašek et al., 2008). This effect has been considered a result of some changes in the rumen microbial population and in its digestive and metabolic activity. Live Saccharomyces cerevisiae cells have been used most often in such experiments (Newbold et al., 1995; Doreau and Jouany, 1998; Lila et al., 2004; Kowalik et al., 2008). Although studies have been numerous, their published results have often been conflicting. For example, live Saccharomyces cerevisiae enhanced or had no effect on total bacteria count and either stimulated or restricted cellulolytic species (Newbold et al., 1995; Callway and Martin, 1997). Similar disagreements concern total as well as specific ciliate counts (Doreau and Jouany, 1998; Lila et al., 2004; Doležal et al., 2005; Kowalik et al., 2008) and fibrolytic and amylolytic activities. For example, Brossard et al. (2006) did not find any differences between the mentioned activities in sheep fed a control diet or the same diet supplemented with live yeast. Conversely, MichaletDoreau et al. (1997) observed a positive effect of live Saccharomyces cerevisiae cells on fibrolytic activity in the rumen. Similarly, the effect of live yeast cells on carbohydrate fermentation in the rumen is also inconsistent (Galip, 2006; Marden et al., 2008). In contrast to live cells, the role of yeast metabolites has been very rarely studied (Arakaki et al., 2000; Miller-Webster et al., 2002).

It is also noteworthy that the published studies have addressed the effects of either only live yeast or only their metabolites. Moreover, additives of different origin and different diets have been used. Comparison of the influence of yeast preparations is thus hardly possible. Unfortunately, comparative studies with the use of the same host animals fed the same diet have been performed only sporadically. The results of such studies were published by Newbold et al. (1998) and Lynch and Martin (2002). The data from these investigations pertain either to the effect of different preparations of live yeast cells or to the effect of live cells and their metabolites under conditions in vitro. 
Thus, the aim of the study was to compare the effect of live Saccharomyces cerevisiae cells and their metabolites on the ciliate count, the activity of $1,4-\beta-\mathrm{D}$ and 1,4;1,6- $\alpha$-D-polysaccharidases, as well as on the concentration of volatile fatty acids and fibre degradability in the rumen of goats.

\section{MATERIAL AND METHODS}

\section{Animals and diets}

The experiment was carried out on three adult female goats $(34 \pm 4.4 \mathrm{~kg}$ liveweight) fitted with permanent rumen fistulae and kept in separate pens. The animals were fed either a control diet $\left(1.2 \mathrm{~kg} \mathrm{DM} \cdot \mathrm{d}^{-1}\right)$ consisting of, \%: meadow hay 63 , barley meal 31 , soyabean meal 4 and $20 \mathrm{~g} \cdot \mathrm{d}^{-1}$ vitamin-mineral mixture (Polfamix - OK) or two experimental diets that were composed of the control diet supplemented with live Saccharomyces cerevisiae (Levucell ${ }^{\circledR}$ SC, S. cerevisiae CNCM I-1077) or its metabolites (Diamond V Mills XP ${ }^{\circledR}$, Cedar Rapids, IA), which were supplied in doses of 3 and $25 \mathrm{~g} \cdot \mathrm{d}^{-1}$, respectively. The composition of the diet is given in Table 1 . The daily ration was offered in two equal portions at 7.00 and $15.00 \mathrm{~h}$. The yeast preparations were given just before the morning feeding. They were administrated directly to the rumen via the fistula. Drinking water was available ad libitum.

Table 1. Composition of diet, \% DM

\begin{tabular}{|c|c|c|c|}
\hline Item & & & \\
\hline Ingredients & & hemical compo. & \\
\hline meadow hay & 63.0 & crude protein & 12.0 \\
\hline crushed barley & 31.0 & organic matter & 88.3 \\
\hline soyabean oilmeal & 4.0 & starch & 23.8 \\
\hline vitamin-mineral premix ${ }^{1}$ & 2.0 & NDF & 52.3 \\
\hline & & $\mathrm{ADF}$ & 25.1 \\
\hline & & ADL & 4.6 \\
\hline & & cellulose & 20.5 \\
\hline
\end{tabular}

${ }^{1}$ premix contents per kg, \%: Ca 24, Na 6, P 12, Mg 6.5; mg: Zn 2500, Mn 3000, Se 3; IU: vit. A 300 000, vit. $\mathrm{D}_{3} 30$ 000, vit. E 1500; DM - dry matter; NDF - neutral detergent fibre; ADF - acid detergent fibre; $\mathrm{ADL}$ - acid detergent lignin

\section{Experiment design and sampling}

The experiment was performed in a $3 \times 3$ Latin square design. Preliminary feeding lasted 3 weeks and was followed by sampling. Fluid and digesta samples were taken from the rumen just before the morning feeding and at 2, 4, 6, 8 and $10 \mathrm{~h}$ thereafter. Each sampling was repeated 2 times on 2 consecutive days. To obtain representative material, samples of digesta and fluid were taken from 
different places in the rumen. Immediately after collection the samples of digesta and fluid were appropriately pooled. The pooled digesta was thoroughly mixed and sampled for determination of ciliate count $(5 \mathrm{~g})$ and enzyme activity $(20 \mathrm{~g})$. The rumen fluid was sampled for determination of VFA. The rumen fluid and digesta that remained after sampling were returned immediately to the rumen. The samples for enzymatic analysis were frozen and kept at $-20^{\circ} \mathrm{C}$, whereas those for protozoa counts were preserved with $4 \%$ formalin solution and stored at room temperature. The samples of rumen fluid for VFA analysis were fixed with formic acid according to Ziołecki and Kwiatkowska (1973) and stored at room temperature.

The influence of yeast additives on digestion of structural carbohydrates and dry matter was examined by a nylon bag technique. Three polyester bags $(8 \times 12 \mathrm{~cm})$ with a pore size of $50 \pm 10 \mu \mathrm{m}$ were filled with $3 \mathrm{~g}$ of ground meadow hay (particle size about $2 \mathrm{~mm}$ ) and incubated in the rumen of the goats for $16 \mathrm{~h}$. After removal from the rumen, the bags were rinsed manually in ice-cold water and then in a washing machine $(2 \times 17 \mathrm{~min})$. The washed bags were dried at $60^{\circ} \mathrm{C}$ to constant weight and the residual hay particles were collected and used for quantification of DM, NDF and ADF. Similar determinations were made using control samples consisting of meadow hay treated similarly but not incubated in the rumen.

Enzymes were extracted from the rumen content with $\mathrm{CCl}_{4}$ (Huhtanen and Khalili, 1992) and the activities carboxymethylocellulase (CMC-ase), xylanase, and amylase were determined according to Michałowski et al. (2003) and Bełżecki et al. (2007) using the dinitrosalicilic acid reagent. The VFA concentration was determined by gas chromatography according to Ziołecki and Kwiatkowska (1973). Rumen fluid acidity was measured immediately after its collection using a Beckman pH-meter. The protozoa were identified and classified after Dogiel (1927) and counted under a light microscope. Feed analyses were performed according to AOAC (1990) methods.

Mean values and the significance of differences between them were determined using the Statistica 9.0 software package. The data were processed by variance analysis in accordance with a linear model:

$$
\mathrm{Y}=\mathrm{A}+\mathrm{P}+\mathrm{T}+\mathrm{e}
$$

where: Y - observation mean; A - animal $(n=3), P$ - period $(n=3), T$ - treatment; e - random error

The significance of differences between means pertaining to dietary treatments was calculated by the Schaffer test. Treatment effects were considered to be significant at $\mathrm{P}<0.01$ and $\mathrm{P}<0.05$. 


\section{RESULTS AND DISCUSSION}

The concentration of ciliates in the rumen of goats is presented in Table 2 . Their total number and the concentration of protozoa from the genus Diplodinium increased significantly when yeast metabolites were given. Similar effects were also found by Arakaki et al. (2000). According to the producer, the mentioned preparation contains such components as B vitamins, organic acids, amino acids, peptides, esters as well as mannans and $\beta$-glucans. Some of them could perhaps be beneficial to ciliates from the genus Entodinium, which dominated in the rumen, and to representatives of the genus Diplodinium. Moreover, the listed components could also stimulate the growth of rumen bacteria, which are engulfed by ciliates and used as the main source of amino acids and some other nutrients (Wiliams and Coleman, 1992). On the other hand, our results agree partially with the findings of Newbold et al. (1998) and Galip (2006), who reported that yeast supplemented to the ration decreased or did not affect the protozoa count.

Table 2. The concentration of ciliates $\left(\times 10^{4} \cdot \mathrm{g}^{-1}\right.$ digesta) in rumen content of goats (mean values; $\mathrm{n}=3$ )

\begin{tabular}{lcccc}
\hline Specification & Control & Live yeast & Yeast metabolites & SEM \\
\hline Total ciliates & $115.0^{\mathrm{A}}$ & $98.0^{\mathrm{AB}}$ & $146.0^{\mathrm{B}}$ & 5.82 \\
Entodinium & 93.0 & 86.0 & 134.0 & 8.39 \\
Diplodinium & $2.5^{\mathrm{a}}$ & $4.5^{\mathrm{ab}}$ & $5.8^{\mathrm{b}}$ & 0.50 \\
Ophryscolex & 1.2 & 3.1 & 1.0 & 0.31 \\
Isotricha & $6.5^{\mathrm{A}}$ & $1.8^{\mathrm{B}}$ & $2.1^{\mathrm{B}}$ & 0.11 \\
Dasytricha & 1.7 & 2.3 & 3.1 & 0.20 \\
\hline
\end{tabular}

values in the row marked with different letters differ significantly: ${ }^{a, b}-\mathrm{P}<0.05$; ${ }^{\mathrm{A}, \mathrm{B}}-\mathrm{P}<0.01$ SEM - standard error of mean values

Conversely to the total protozoa count and that of ciliates from the genus Diplodinium, the population density of Isotricha sp. decreased about eightfold when the supplements were added to the control diet (Table 2). These results thus suggest that the yeast preparation negatively affected the factors required by large holotrichs for growth. Conversely, the addition of yeast did not modify the population density of ciliates from the genus Dasytricha, which is in accordance with the results of Brossard et al. (2006) and Galip (2006) concerning holotrich ciliates. These results suggest that these protozoa were either less sensitive than the representatives of genus Isotricha to the changes in the rumen ecosystem caused by the supplemented additives or that the yeast preparation did not influence the growth conditions required by these microorganisms from the family Isotrichidae (Kowalik et al., 2008). In contrast to our finding, Arakaki et al. (2000) showed that yeast metabolites increased the population density of Dasytricha in the rumen of steers. The above consideration also seems to be valid for ciliates from the genus Ophryoscolex. 
Of the fibrolytic enzymes, only CMC-ase, endocellulase and xylanase were tested (Table 3). Both activities increased significantly when the control rations were enriched either with live Saccacharomyces cerevisiae or with its metabolites. These results are in agreement with the findings of Moharrery and Asadi (2009) who reported that the activity of cellulase increased in the rumen of lambs fed a mixture of malate and Saccharomyces cerevisiae yeast. The higher activity of xylanase in animals fed live yeast agrees with results published by Michalet-Doreau et al. (1997). It can not be precluded that the increase in fibrolytic activity could result from the increase in the number of cellulolytic ciliates from the genus Diplodinium, for example, Eudiplodinium maggii, Diploplastron affine and Anoplodinium denticulatum, which were present in the rumen of goats and which exhibit high cellulolytic and xylanolytic activity (Michałowski et al., 2003; Stan et al., 2006).

Table 3. The activity of carboxymethylocellulase (CMC-ase), xylanse and amylase ( $\mu \mathrm{M}$ released reducing sugars $\cdot \mathrm{g}^{-1} \mathrm{DM} \cdot \mathrm{min}^{-1}$ ) in the rumen content of goats (mean values; $\mathrm{n}=3$ )

\begin{tabular}{lcccc}
\hline Enzymes & Control & Live yeast & Yeast metabolites & SEM \\
\hline CMC-ase & $8.0^{\mathrm{a}}$ & $9.4^{\mathrm{b}}$ & $9.4^{\mathrm{b}}$ & 0.25 \\
Xylanase & $57.5^{\mathrm{a}}$ & $69.7^{\mathrm{b}}$ & $70.4^{\mathrm{B}}$ & 1.49 \\
Amylase & $58.1^{\mathrm{a}}$ & $49.7^{\mathrm{b}}$ & $51.2^{\mathrm{ab}}$ & 1.56 \\
\hline
\end{tabular}

values in the row marked with different letters differ significantly: ${ }^{a, b}-\mathrm{P}<0.05$; ${ }^{\mathrm{A}, \mathrm{B}}$ - $\mathrm{P}<0.01$

SEM - standard error of mean values

In the present study it was found that the amylolytic activity in the rumen decreased significantly when the control diet fed to the goats was replaced by the ration supplemented with live yeast (Table 3 ). This drop presumably reflected the changes in microbial population. The data presented in Table 2 show that the live yeast negatively influenced the number of Isotricha and positively that of Diplodinium. The protozoa from both groups exhibit amylolytic properties (Williams,1986; Williams and Coleman, 1992) but their effect on amylase activity in the rumen was not examined. Such activity depends rather on the number and activity of amylolytic bacteria, but these were not monitored in this study. In contrast to our result, Moharrery and Asadi (2009) found a positive effect of yeast on the activity of amylolytic enzymes in the rumen of lambs. In contrast, Brossard et al. (2006) and Kowalik et al. (2008) did not observe any effect of yeast on the mentioned activity. Further studies are thus necessary. 
The effect of the addition of a yeast preparation to the control diet on dry matter and structural carbohydrate digestion is presented in Table 4. Live

Table 4. Dry matter and structural carbohydrates of meadow hay degradability after $16 \mathrm{~h}$ incubation in the rumen of goats, in sacco, \% (mean values; $\mathrm{n}=3$ )

\begin{tabular}{lcccc}
\hline Specification & Control & Live yeast & Yeast metabolites & SEM \\
\hline Dry matter & 55.0 & 57.2 & 54.8 & 0.63 \\
NDF & $37.9^{\mathrm{a}}$ & $44.7^{\mathrm{b}}$ & $38.3^{\mathrm{ab}}$ & 1.01 \\
ADF & 33.3 & 35.4 & 34.2 & 1.00 \\
\hline
\end{tabular}

values in the row marked with different letters differ significantly: ${ }^{a, b}-\mathrm{P}<0.05$; SEM - standard error of mean value; NDF - neutral detergent fibre; ADF - acid detergent fibre

Saccharomyces cerevisiae increased the disappearance of NDF by about $7 \%$ $(\mathrm{P}<0.05)$. An improvement in NDF disappearance as a result of supplementation of yeast to the ration has been reported previously in experiments performed in vivo and in vitro (Plata et al., 1994; El-Waziry and Ibrahim, 2007). Increased NDF digestion may be attributed to the enhancement of the numbers of viable and cellulolytic bacteria (Lila et al., 2004). Newbold et al. (1996) suggested that the ability of different strains of Saccharomyces cerevisiae to stimulate the number of viable bacteria in the rumen appears to be related to their ability to remove oxygen from rumen fluid. On the other hand, Plata et al. (1994) claimed that the improvement of NDF digestion in the rumen of steers may partially be explained by the increase in the density of the protozoa population. In our experiment, the total number of protozoa did not change after enrichment of the control diet with live yeast, but a numerical increase in the population density of ciliates from the genus Diplodinium was observed (Table 2). It is well known that some species from this group are characterized by high cellulolytic and, especially, xylanolytic activity (Michałowski et al., 2003; Stan et al., 2006). Our results thus support the suggestion of the authors cited above but contradict the results of Arcos-García et al. (2000) who did not observe increased digestibility of cell wall carbohydrates in the rumen when fungal preparations were added to the ration. Supplementation of live Saccharomyces cerevisiae to the ration did not increase the degradability of DM ( $>0.12)$ or ADF ( $>0.35)$ (Table 4). Doreau and Jouany (1998) did, however, observe increased disappearance of only ADF, but not DM and NDF, from maize stalk incubated in sacco for $6 \mathrm{~h}$ in the rumen of dairy cows fed a diet supplemented with live Saccharomyces cerevisiae. The cited authors suggest that the concentration of live organisms increased during the first hour after feeding and that this was followed by an increase in the degradation of dietary structural carbohydrates. The studies concerning the role of live Saccharomyces cerevisiae in the digestion of plant cell wall polysaccharides will thus be continued. 
The results of $\mathrm{pH}$ measurements in the rumen fluid of goats are given in Table 5. Inclusion of yeast metabolites to the diet resulted in a significant increase of ruminal $\mathrm{pH}$ compared with both of the other treatments, i.e. control animals and goats fed the ration supplemented with live yeast. According to

Table 5. The influence of live Saccharomyces cerevisiae and their metabolites on $\mathrm{pH}$, concentration of total volatile fatty acids $\left(\mathrm{mmol} \cdot \mathrm{l}^{-1}\right)$ and molar proportion of particular acids in the rumen of goats ( $\%$ of total VFA) (mean values; $n=3$ )

\begin{tabular}{|c|c|c|c|c|}
\hline Item & Control & Live yeast & Yeast metabolites & SEM \\
\hline$\overline{\mathrm{pH}}$ & $6.5^{\mathrm{a}}$ & $6.4^{\mathrm{Aa}}$ & $6.7^{\mathrm{Bb}}$ & 0.03 \\
\hline Total VFA & $43.4^{\mathrm{A}}$ & $42.5^{\mathrm{A}}$ & $39.2^{\mathrm{B}}$ & 0.40 \\
\hline Acetate (A) & $62.7^{\mathrm{a}}$ & $63.9^{\mathrm{b}}$ & $63.4^{\mathrm{ab}}$ & 0.18 \\
\hline Propionate $(\mathrm{P})$ & $23.9^{\mathrm{Aa}}$ & $21.1^{\mathrm{B}}$ & $22.3^{\mathrm{b}}$ & 0.18 \\
\hline Butyrate & $10.5^{\mathrm{a}}$ & $11.9^{\mathrm{b}}$ & $11.3^{\mathrm{b}}$ & 0.18 \\
\hline Other acids ${ }^{1}$ & 2.9 & 3.1 & 3.1 & 0.07 \\
\hline A: P & $2.7^{\mathrm{Aa}}$ & $3.1^{\mathrm{B}}$ & $2.9^{\mathrm{b}}$ & 0.03 \\
\hline
\end{tabular}

Mutsvangwa et al. (1992), the rise in $\mathrm{pH}$ may reflect the carbohydrate fermentation/ volatile fatty acid absorption ratio as well as the buffering capacity of rumen fluid. On the other hand, Miller-Webster et al. (2002) supposed that the ruminal $\mathrm{pH}$ may depend on the kind of fungal population. They showed that the addition of a yeast Diamond-V XP preparation to the ration significantly lowered ruminal $\mathrm{pH}$ in comparison with the effect of A-Max yeast. The relevant $\mathrm{pH}$ values presented there were 6.2 and 6.4, respectively. The rise in ruminal $\mathrm{pH}$ could also follow a drop in lactic acid concentration. Such changes could be the result of the enhancement in the activity and/or number of lactate fermenting bacteria such as Megasphaera elsdenii and Selenomonas ruminantium. On the other hand, Sullivan and Martin (1999) did not find significant changes in the acidity of rumen fluid after addition of yeast metabolites to the ration. Moreover, Lynch and Martin (2002) reported that the $\mathrm{pH}$ decreased when ruminal microorganisms were incubated in vitro in the presence of lucerne or Bermuda grass supplemented with yeast metabolites. In turn, Kř́žžovă et al. (2011) observed a rise in pH from 6.16 to $6.26(\mathrm{P}<0.001)$ in the rumen of cows after supplementation of the control diet with live yeast.

The data on volatile fatty acids are presented in Table 5. Surprisingly, the concentration of total VFA was very low and did not exceed $43.4 \mathrm{mmol} \cdot \mathrm{l}^{-1}$. This is in the range reported recently by Křížovă et al. (2011) in cows fed a maize silage-concentrate diet supplemented with live yeast cultures. Unfortunately, those authors did not explain their findings. Further studies therefore seem to be necessary to identify the causes of the obtained results. The VFA concentration was significantly higher in goats fed the control diet or ration supplemented with 
live yeast than in animals receiving the ration enriched with yeast metabolites. Doležal et al. (2005) and Marden et al. (2008) reported that live Saccharomyces cerevisiae increased total VFA in the rumen of cows. In contrast to the cited authors, Brossard et al. (2006) and Galip (2006) showed that live yeast cells did not modify total VFA, but according to Doreau and Jouany (1998), the effect of live yeast on total VFA in rumen of dairy cows was transient.

The molar proportion of acetate and butyrate in ruminal VFA was increased and propionate was decreased when both fungal additives were added to the control diet. Furthermore, the acetate-to-propionate ratio was lower in control animals compared with the goats fed the diet containing a yeast preparation. Newbold et al. (1995) have reported that live yeast added to the diet fed to sheep decreased propionate concentrations. On the other hand, Arcos-García et al. (2000) and Galip (2006) did not observe any significant changes in the propionate concentrations in cows fed control and experimental rations. The increase in acetate concentration in the rumen of goats receiving a diet supplemented with live yeast might result from the increase in the number of cellulolytic bacteria, as the enhanced acetate level was associated with a higher activity of fibrolytic enzymes and with increased disappearance of NDF from hay incubated in sacco in the rumen. Our results are also in agreement with other studies focused on the effect of live yeast on the concentration of acetate in the rumen (Marden et al., 2008; Krŕžžovă et al., 2011). In contrast, Brossard et al. (2006) did not observe an increase in the ruminal acetate concentration in sheep. In the present study, the greater molar proportion of butyrate and acetate in goats fed a diet supplemented with a fungal preparation was associated with an increase in the number of protozoa. According to Michałowski (1987), ciliates produce mainly acetic and butyric acids. The authors found that acetate and butyrate contributed to 52.9 and $41.3 \%$ of the total VFA produced by ciliates in the rumen of sheep, respectively. A positive correlation was also found there between the production of VFA by protozoa and the total biomass of ciliates as well as the biomass of medium- and large-sized ciliates. Thus, the changes in ciliate counts and, especially, that of Diplodinium should not be ignored in the consideration of changes in the molar proportion of volatile fatty acids that are presented in Table 5.

\section{CONCLUSIONS}

Ayeast preparation added to the diet of goats can differently modify the protozoal fauna and metabolism in the rumen. Our data showed that live Saccharomyces cerevisiae cells positively influenced endocellulase and xylanase activities, as well as the disappearance of cell wall carbohydrates and molar proportion of acetate and butyrate and negatively that of propionate. Supplementing the diet with yeast 
metabolites increased the total number protozoa and the number of ciliates from the genus Diplodinium, as well as fibrolytic enzyme activities and rumen fluid acidity.

\section{REFERENCES}

AOAC, 1990. Association of Official Analytical Chemists, Official Methods of Analysis. 15 $5^{\text {th }}$ Edition. Arlington, VA

Arakaki L.C., Stahringer R.C., Garrett J.E., Dehority B.A., 2000. The effect of feeding monensin and yeast culture, alone or in combination, on the concentration and generic composition of rumen protozoa in steers fed on low-quality pasture supplemented with increasing levels of concentrate. Anim. Feed Sci.Tech. 84, 121-127

Arcos-García J.L., Castrejón F.A., Mendoza G.D., Pérez-Gavilán E.P., 2000. Effect of two commercial yeast cultures with Saccharomyces cerevisiae on ruminal fermentation and digestion in sheep fed sugar cane tops. Livest. Prod. Sci. 63, 153-157

Bełżecki G., McEwan N.R., Newbold C.J., McIntosch F.M., Michałowski T., 2007. Characterization of the amylolytic properties of the rumen ciliate protrozoan Eudplodinium maggii. J. Anim. Feed Sci. 16, 590-606

Brossard L., Chaucheyras-Durand F., Doreau B.M., Martin C., 2006. Dose effect of live yeasts on rumen microbial communities and fermentations during butyric latent acidosis in sheep: new type interaction. Anim. Sci. 82, 829-836

Callaway E.S., Martin S.A., 1997. Effect of Saccharomyces cerevisiae culture on ruminal bacteria that utilize lactate and digest cellulose. J. Dairy Sci. 80, 2035-2044.

Dogiel V.A., 1927. Monographie der Familie Ophryoscolecidae. Arch. Protistenk. 59, 1-288

Doleźal P., Doleźal J., Trinacty J., 2005. The yeast culture Saccharomyces cerevisiae on ruminal fermentation in dairy cows. Czech J. Anim. Sci. 50, 503-510

Doreau M., Jouany J.P., 1998. Effect of a Saccharomyces cerevisiae culture on nutrient digestion in lactating dairy cows. J. Dairy Sci. 81, 3214-3221

Galip N., 2006. Effect of supplemental yeast culture and sodium bicarbonate on ruminal fermentation and blood variables in rams. J. Anim. Physiol Anim. Nutr. 90, 446-452

El-Waziry A.M., Ibrahim H.R., 2007. Effect of Saccharomyces cerevisiae of yeast on fiber digestion in sheep fed berseem (Trifolium alexandrinum) hay and cellulose activity. Austr. J. Basic Appl. Sci. 1, 4, 379-385

Huhtanen P., Khalili H., 1992. The effect of sucrose supplements on the particcle-associated carboxymethylcellulase (EC 3.2.1.4) and xylanase (EC 3.2.1.8) activities in cattle given grasssilage-based diet. Brit. J. Nutr. 76, 245-255

Kowalik B., Michałowski T., Pająk J.J., Taciak M., Rawa J., 2008. The effect of supplementing cows with live yeast Saccharomyces cerevisiae on the ciliate fauna and ruminal fermentation. J. Anim. Feed Sci. 17, 157-165

Kř́žzovă L., Richter M., Třinăctỳ J., Říha J., Kumprechtovă D., 2011. The effect of feeding live yeast cultures on ruminal $\mathrm{pH}$ and redox potential In dry cows as continuously measured by a new wirelees device. Czech J. Anim. Sci. 56, 1, 37-45

Lynch H.A., Martin S.A., 2002. Effect of Saccharomyces cerevisiae culture and Saccharomyces cerevisiae live cell on in vitro mixed ruminal microorganism fermentation. J. Dairy Sci. 85, 2603-2608

Lila Z.A., Mohammed N., Yasui T., Kurkawa Y., Kanada S., Itabashi H., 2004. Effect of twin strain of Saccharomyces cerevisiae live cells on mixed ruminal microorganism fermentation in vitro. J. Anim. Sci. 82, 1847-1854 
Marden J.P., Julien C., Monteils V., Auclair E., Moncoulon R., Bayourthe C., 2008. How does live yeast differ from sodium bicarbonate to stabilize ruminal $\mathrm{pH}$ in high-yielding dairy cows? $\mathrm{J}$. Dairy Sci. 91, 3528-3535

Mašek T., Mikulec Ž., Valpotić H., Kušće L., Mikulec N., Antunac N., 2008. The influence of live cells (Saccharomyces cerevisiae) on the performance of grazing dairy sheep in late lactation. Vet. Arhiv. 78, 2, 95-104

Michalet-Doreau B., Morand D., Martin C., 1997. Effect of the microbial additive Levucell ${ }^{\circledR}$ SC on microbial activity in the rumen during the stepwise adaptation of sheep to high concentrate diet. Rep. Nutr. Dev. 37, Suppl. 1 81-82

Michałowski T., 1987. The volatile fatty acids production by ciliate protozoa on the rumen of sheep. Acta Protozool. 26, 4, 335-345

Michałowski T., Bełżecki G., Kwiatkowska E., Pająk J.J., 2003. The effect of selected rumen fauna on fibrolytic enzyme activities, bacterial mass, fibre disappearance and fermentation pattern on sheep. J. Anim. Feed Sci. 12, 45-64

Miller-Webster T., Hoover W.H., Holt M., Nocek J.E., 2002. Influence of yeast culture on ruminal microbial metabolism in continuous culture. J. Dairy Sci. 85, 2009-2014

Moharrery A., Asadi E., 2009. Effects of supplementing malate and yeast culture (Saccharomyces cerevisiae) on rumen enzyme profile and growth performance of lambs. J. Anim. Feed Sci. 18, 283-295

Mutsvangwa T., Edwards I.E., Topps J.H., Peterson G.F.M., 1992. The effects of dietary inclusion of yeast culture (Yea-Sacc) on patterns of rumen fermentation, food intake and growth of intensively fed bulls. Anim. Prod. 55, 35-40

Newbold C.J., McIntosh F.M., Wallace R.J., 1998. Changes in the microbial population of a rumensimulating fermenter in response to yeast culture. Can. J. Anim. Sci. 78, 214-244

Newbold C.J., Wallace R.J., Chen X.B., McIntosh F.M., 1996. Mode of action of the yeast Saccharomyces cerevisiae as a feed additive for ruminants. Brit. J. Nutr. 76, 249-261

Newbold C.J., Wallace R.J., Chen X.B., McIntosh F.M., 1995. Different strains of Saccharomyces cerevisiae differ in their effect on ruminal bacterial numbers in vitro and in sheep. J. Anim Sci. $73,1811-1818$

Plata F., Mendoza G.D., Bárcena-Gama J.R., Gonzalez S.M., 1994. Effect of a yeast culture (Saccharomyces cerevisiae) on neutral detergent fiber digestion in steers fed oat straw based diets. Anim. Feed Sci. Tech. 49: 203-210

Stan K., Bełżecki G., Kasperowicz A., Kwiatkowska E., Michałowski T., 2006. The ability of the rumen ciliates Anoplodinium denticulatum to utilize hemicellulosic material for in vitro growth. J. Anim. Feed Sci. 15, Suppl. 1, 39-42

Sullivan H.M., Martin S.A., 1999. Effects of Saccharomyces cerevisiae culture on in vitro mixed ruminal microorganism fermentation. J. Dairy Sci. 82, 2011-2016

Williams A.G., 1986. Rumen holotrich ciliate protozoa. Microbial. Rev. 50, 25-49

Williams A.G., Coleman G.S., 1992. The rumen protozoa. Springer-Verlag, New York

Ziołecki A., Kwiatkowska E., 1973. Gas chromatography of $\mathrm{C}_{1}$ to $\mathrm{C}_{5}$ fatty acids in rumen fluid and fermentation media. J. Chromatogr. 80, 250-254 